\title{
Mathematical Modelling Approach in Mathematics Education
}

\author{
Ayla Arseven \\ Faculty of Education, Cumhuriyet University, Turkey
}

Copyright (C) 2015 by authors, all rights reserved. Authors agree that this article remains permanently open access under the terms of the Creative Commons Attribution License 4.0 International License

\begin{abstract}
The topic of models and modeling has come to be important for science and mathematics education in recent years. The topic of "Modeling" topic is especially important for examinations such as PISA which is conducted at an international level and measures a student's success in mathematics. Mathematical modeling can be defined as using mathematics to explain and define the events in real life, to test ideas and to make estimations about real life events. Theoretical basis of the mathematical modelling approach, "model", "mathematical modelling" and "modeling activity" concepts are explained in this study and examples of these concepts are given. The importance of mathematical modeling, importance and the place of modeling topic in primary school, secondary school and high school (secondary education) mathematic programs based on social constructive approach, which were developed in 2005 and modified in 2013 by the Ministry of National Education (MNE) in Turkey, and how the modeling activities are included in the program are also presented in this study. It is considered that this study will contribute to the mathematical program development studies by MNE which are developed based on the constructive approach in Turkey.
\end{abstract}

Keywords Mathematic Teaching, Mathematical Modelling Approach, Mathematics Curriculum

\section{Introduction}

Rapid development of information and technology today changed society's expectations form people and education world. Today's world expects mathematics teachers to raise individuals who are able to create effective solutions in cases of real problems and use mathematics effectively in their daily lives. Thus, they will enjoy mathematics instated of being scared of it and comprehend and appreciate the importance and power of mathematics [10]. This process of development and change caused new searches in our educational system and it became compulsory to try new approaches, methods and models in the educational realm.
One of those new approaches in mathematics teaching is teaching by means of models. According to Pesen [21] models are concrete entities, pictures and objects in which some states of a concept desired to be developed are represented. Students are very interested in this approach.

The main reason why mathematics is the most comprehensive education area of the world is mathematics could be used in various ways in areas and topics that is not related to it. Mathematics is always used outside itself, in a covered manner or clearly especially in cases of problems, situations or areas including mathematical models and modeling [16]. According to Freudenthal, mathematics is not a closed system or a subject that should be learned but a human activity and it has to have a relation with the reality [13].

When relevant literature in mathematical modeling is reviewed, it is seen that many studies have been carried out on this topic abroad. However, in Turkey few studies have been conducted with regard to the use of modeling approach in teaching math $[7,15]$. Besides, the concepts of mathematical modeling and modeling are not clearly defined in our literature. In this study, the term mathematical modeling is explained and examples of model given in foreign literature and appropriate examples of models that mathematics teachers and prospective mathematics teachers can benefit in their teaching practices are presented. This study discusses mathematical modeling from a theoretical aspect together with in-class implementations of it in primary, secondary and high schools in Turkey.

Individuals who learn using the constructivist approach constructs knowledge individually and reorganize it. To achieve this, learners are to be engaged in problem solving and discovery activities, in discussions with their teachers and peers and in experiences in which they can express their meanings in different ways. Constructivism argues that learning does not take place through transferring knowledge but it can occur as a result of asking questions, researching and solving problems [12].

The new education programs developed by the Ministry of National Education (MNE) in 2005 (Turkish, Math, Social Studies and Science and Technology courses) are based on 
the constructivist approach and multiple intelligences theory. Accordingly, instructional strategies and methods in which learners are active are used. The most significant difference between traditional and the constructivist approach is the difference in terms of teaching and learning processes. There has been a shift from a teacher and teaching focused approach, to student and learning focused approach. Therefore, teaching strategies, methods and techniques used in learner-centered classes in general include the cooperative learning method, role play, act-out activities, games, discovery activities, and in mathematics in particular realistic mathematical teaching method, discovery learning strategy, math games and mathematical modeling approach are used.

\section{Method}

The study is a "basic research", which is one of the quantitative research methods. Basic research is carried out to establish a theory or model in a field of study, to strengthen or contribute to existing ones, or to test a theory [20]. Basic research studies are intended to create knowledge and theoretical understanding with regard to basic human processes and other natural processes [12]. In the study, relevant foreign and Turkish literature and primary school, secondary school and high school mathematics educational programs developed by MNE have been reviewed and theoretical structure of the mathematical modeling approach is presented with examples. Besides, theoretical structure with regard to the current state of educational programs in Turkey has been discussed.

1. Mathematical modeling and Instructional Approaches Using Mathematical Modeling

According to Boaler [2], mathematical modelling theory focuses on individuals and suggests that knowledge is created as a result of a series of interactions between people and the world. This situation requires examination of students' situations with different practices. For this reason, it becomes important to present students with situations in which they use the knowledge and have application opportunities.

Mathematical modelling is defined as the transformation of any problem situation into a mathematical model. However this concept started to be used commonly to define the process including all the steps of structuring mathematizing, mathematical working and interpretation/verification. Sometimes the problem situation that is given is nothing else than a pre-structured mathematical problem or a mathematical problem that is full of real life. This is the classic "word problem" situation that generally occurs in schools. Using mathematics to solve problems that are encountered in real life is called as application of mathematics. Sometimes the application concept is used for a relation that binds real life to mathematics. In the last ten years "application and modeling" concepts were used to explain any relations between real life and mathematics [3].

According to Olkun et al. [19], developing approaches that could discover patterns and relations and application of these patterns and relations in solving other problems are aimed in the modeling approach. Thus, through modeling the aim is to enable the students developed the skill to generalize, which is one of the basic skills in mathematical teaching.

Mathematical modelling (a bi-directional process between daily life and mathematics) has become one of the most discussed and widely known topics in mathematics teaching in recent years. However, less than desired level of interest is shown to modeling topic throughout the world. The main reason for this is that it is hard for students and teachers because of the gap between the educational objectives and school practices (Lesh and Doerr 2003a). In fact, mathematics is a discipline whose teaching and learning is considered to be difficult. This difficulty results from the complex nature of mathematics. Another reason for that is to do with the "external meaning" of the mathematical thinking. For example, what does "half of something" mean? For this reason, it is important to relate mathematics with events and applications in our environment. However, it is not that simple to do this. An important part of mathematics is formed of rules and discovered systems that are self-consistent. Value system of the numbers is an example for that. Children conduct activities regarding the qualities of systems and relations of number during the preschool period. Later, they learn how they will manipulate algebraic expressions. Thus, they reach reality, which is the next step. Mathematical terms may have many different meanings. For example, a fraction can be interpreted as a part of a whole, a ratio between two quantities or division of one number to another. This corresponds to a decimal number, fraction or percentage forms [26].

Blum and Ferri [4] showed the cycle of the modelling process in 7 steps given below in order to help the cognitive analysis of the modeling situations, which they also used in their projects. Mathematical expression of a problem and the process of solving this problem by putting real life aside are shown in a cyclic manner in these steps.

1. Understanding the situation (problem)

2. Simplifying/structuring

3. Mathematizing

4. Mathematical working

5. Interpretation

6. Verification

7. Presentation 


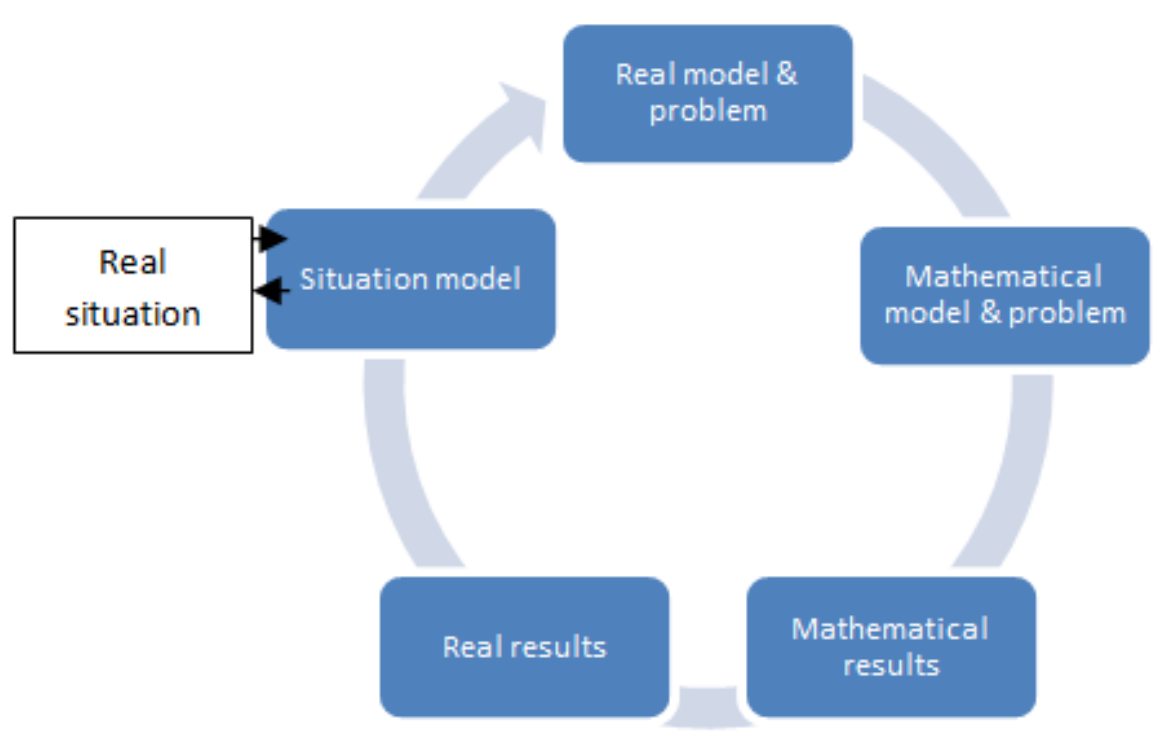

Figure 1. Modelling Cycle [11]

Firstly, the problem situation should be understood by the student, that is to say, "the situation model" is formed. After that, the situation is structured and turned into "a real model". The student should decide especially on what is worth doing at this point. During the mathematizing process, which corresponds to the third step, the student turns "the real model" into a "mathematical model". The student conducts "a mathematical work (calculation, solving inequalities etc.)" and reaches "the mathematical results" at the fourth step. Real results in the daily life are interpreted and verified during the fifth step. Finally the possible solutions of the problem are presented and suggestions are made regarding the problem.

According to Galbraith (1989), there are 3 different teaching approaches in modelling. These are as follows:

1) "General application approach" focuses on a certain application. Generally, the teacher introduces the model and the students use the model in a controlled manner. This approach is mostly used in secondary schools and it includes 4th (calculation, solving inequalities etc.) and 5th steps (real results in the daily life are interpreted and verified) of the modeling process.

2) "Structure modeling approach" uses the real life situations and covers all the stages of the modeling process form the 1 st stage (the problem situation should be understood by the student) to the 7th stage (the possible solutions of the problem are presented). The teacher makes an important effort to make mathematical model used in the 3rd stage (mathematizing process).

3) "Open modeling approach". In this approach, students work with the limited help of the teacher about the problem that is given because teacher does not have to control the students. This approach is not used widely [25].

2. Mathematical Modeling Activity and Activity Samples Mathematical modelling activities are mathematical modeling conducted by students in the classroom environment. The students, who work in small groups during these activities, develop the mathematical interpretations of the problem situations on their own and mathematizing the situations that are given. These activities are developed within the framework of the themes the children are interested in and they are organized in a way that will encourage children to study and clarify the problem situation. At the end of modeling activities, the students present the models they developed to their friends using various illustration systems such as written symbols, verbal reports, diagrams on paper or pictures [9].

As an example of modeling activities, "big foot problem", which is a problem situation regarding real life and which is adapted by Lesh and Doerr (2003a) to the second level of primary education. This modeling activity is organized as follows:

\section{Model Example}

"The Giant's Shoe"

There is a pair of shoes in a sport center in the Philippines. According to Guinness Book of the World Records, it is the largest shoe of the world with the width of $2.37 \mathrm{~m}$ and the length of $5.29 \mathrm{~m}$. What is the height of the giant that could actually wear these shoes?

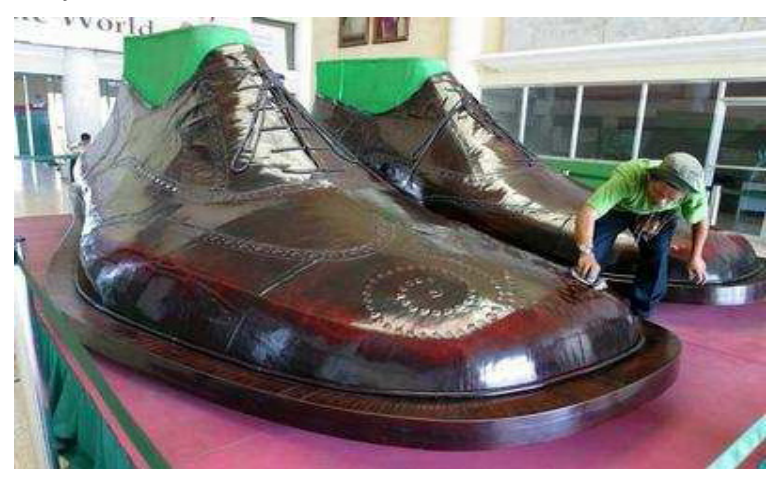

Figure 2. The giant's shoe 
This problem can be defined as mathematical modeling since it requires a translation between mathematics and the reality. In fact, according to Pollak (1979), by the terms "the whole world outside the mathematics area" we mean nature, society, daily life and other scientific disciplines [4].

The modelling activity developed by four high school mathematics teachers were organized as follows in the study named "Examination of Model Activity Design Process of Mathematics Teachers: Obesity Problem" by Dede and Güzel [8].

Mother and father of Can, who is an $8^{\text {th }}$ grade student, works in a private company. His parents go to work early in the morning and come back late in the evening. For this reason, Can does not have the habit of proper nutrition; he turns to convenience food and high calorie foods. As a result of this, he started gaining weight rapidly. Can, who is $1.60 \mathrm{~m}$ tall, comes to weigh $82 \mathrm{~kg}$. Recognizing this situation, his mother took Can to a dietitian. Dietitian said that Can is classified as an obese person.

Dietitian suggested an exercise program to Can, which he will apply without changing the amounts of daily calories he takes. According to this, Can will start with an exercise of 20 minutes per day and 3 days a week and he will continue to do the exercises by increasing the time of exercises 5 minutes each week. He will choose one exercise from the table below and he will not change his choice. The table showing which exercise corresponds to how many calories is given below.

(Note: 9 calories should be spent for 1 gram of oil)

Table 1. Sample table

\begin{tabular}{|c|c|c|}
\hline Working with weights & 30 minutes & 150 calories \\
\hline Skating & 15 minutes & 15 calories \\
\hline Climbing up stairs & 15 minutes & 15 calories \\
\hline Dancing & 30 minutes & 75 calories \\
\hline Riding a bicycle & 30 minutes & 300 calories \\
\hline Playing tennis & 30 minutes & 120 calories \\
\hline Going for a walk & 20 minutes & 60 calories \\
\hline Playing basketball & 30 minutes & 300 calories \\
\hline Swimming & 30 minutes & 300 calories \\
\hline Playing volleyball & 1 hour & 180 calories \\
\hline
\end{tabular}

Develop a model that will enable Can to find out how many weeks it will take him to reach the weight he aims for according to the activity he chooses and to help him, write a letter explaining this in detail.

Mathematical modeling development is a complex process in mathematical and scientific application in real. There are no standards showing how the student will learn about both areas of mathematics and science by associating them with real life events and conducting authentic activities. Such an integrative approach reveals the complexity of the mathematical modeling with one question: "What is the meaning of abstraction, formulation and generalization in applications and modeling? In more traditional mathematics and science, this question addresses the epistemological thinking suggesting the abstract realities are valuable for the connection between the real events and mathematics. This situation considers not only cognitive process and student thinking in classroom but also examination of social practices as needs. In both cases, abstraction is the basic role and the focus point of the investigation [6].

\section{The Importance of Mathematical Modeling and Difficulty in Teaching it}

A community among the mathematics students, which grow bigger since the end of the 1960s, gave special importance to mathematical applications, models and modeling in mathematics teaching and learning. This importance is based on two ideas which are different but certainly compatible with each other. The first idea defended the slogan "mathematics for applications, models and modeling". According to this, primary aim and task in mathematics teaching is to stimulate mathematical activities of students of various proficiency levels by using practical activities. The second idea defends the slogan "applications, models and modeling for mathematics". That is to say, being interested in mathematical activation in contexts that are not mathematical increases motivation of the students and feeds the formation of affective qualities, conceptual thinking and mathematical thinking power. The approach called "Realistic Mathematics Education" brought forward by Freudenthal Institute in Holland is an example for this situation [16].

Non-mathematical contexts have had an important place in mathematics teaching in Holland since 1985. Modeling topic has been included in all mathematics programs in secondary school since 1998 [23].

Why is modeling so important for students? Mathematical models and modeling exist all around us, we especially encounter them in technological devices. It is necessary to form modeling qualifications of the students while preparing them as citizens responsible for society and become part of society. More generally, mathematical modelling;

- Helps students to understand the world better,

- Supports mathematical learning (motivation, concept formation, giving meanings etc.)

- Ensures developing various mathematical qualifications and accurate attitudes.

- Provides sufficient support for the framework of mathematics.

Mathematics becomes more meaningful for the students with modeling. Development of mathematical modeling skills of students is underscored as one of the main objectives of mathematics teaching in the secondary school program in Germany. However, there are still very few examples of modeling in mathematics teaching practices in many countries. The reason of the gap between the programs and educational practices is that the mathematical modeling is also difficult for teachers. Because it requires real life knowledge, the teaching becomes more open and less applicable [4]. With regard to this, it is considered that if teachers learn the theoretical basis of modeling approach in pre-service university education and if they can create 
modeling primary school, secondary school and high school level they will not have difficulty in teaching them practically when they start teaching. In other words, prospective teachers are to be trained to be knowledge in this topic.

In reality, mathematical and scientific application, development of modeling is a complicated process. There are not standards about how to teach mathematics and science in relation to real world events through authentic activities. Such an approach reveals the complexity of mathematical modeling with a question: "What is the reasoning of abstraction, formulization and generalization in implementations and modeling? (cited in ICMI)" This question in more traditional mathematics and science turns to epistemological thinking to indicate that abstract realities are important in the connection between mathematics and real event. This case regards the need to examine not only cognitive process and student thinking but also social implementations in the class. In both cases, abstraction is the basic function and focal point of inquiry [5].

From childhood to adolescence, people learn about abstract mathematical relations with concrete objects and by interacting with their peers. A student develops mathematical knowledge by examining a model appropriate for this knowledge, that is to say, he rebuilds it. Models can be used for three different purposes in mathematics teaching.

- To ensure that students develop new concepts and relations, which is especially useful in the introduction stage of a new unit.

- To help students establish relations between concepts and symbols; a student who has learned concepts and rules can establish the relations between those by using models.

- To measure the understanding level of students; students show the mathematical relations by meddling with the objects [18].

According to Özdemir and Üzel [20], modeling makes an important contribution in terms of developing problem solving skills of students. Also, modeling emphasizes mathematical relations and ensures for students to develop their learning styles and understanding of mathematics. Modeling helps teachers communicate with their students and motivate them. Teaching and learning the topic of modeling is difficult. However, a teacher can facilitate and develop students' modeling qualifications by developing education activities.

\section{Modelling and Modelling Activities in Ministry of National Education's (MNE) Primary School - Secondary School and Secondary Education (High School) Mathematics Curricula in Turkey}

It is suggested in Primary Education Mathematics Curriculum, which was put into practice in 2005, students' "model formation skills and skills for associating models with verbal and mathematical expressions" are considered among the objectives of mathematics education [1].

It was underlined in primary education mathematics curriculum prepared by MNE [22] that teachers should take into consideration some teaching strategies in order to successfully apply primary education mathematics program. These are listed as follows:

1) Teaching should start with concrete experiences.

2) Meaningful learning should be aimed.

3) Students should establish communication by using their mathematical knowledge.

4) Importance should be given to association.

Students at a young age learn more meaningfully in learning environments within which knowledge is represented by concrete models. Therefore, situations in which knowledge is represented differently should be used in teaching (symbols, concrete tools, pictures, verbal and written expressions etc.). Also, it is important to associate mathematical knowledge with both real life and things learned in other lectures. For this reason, problems should be chosen in a way to help students clearly see the use of mathematics in the daily life. It is stated in the program that gains of the students will be more useful when they see that mathematics can also be used in other lectures.

Primary school mathematics curriculum focuses on 4 mathematical skills such as "problem solving", "communication", "association" and "reasoning". In relation to problem solving skill, which can be considered as the most important skill for mathematics lesson, it is stated that problem should not be approached in an algorithmic and rule-based manner and how a student solves a problem, how he represents a problem situation (table, figure, concrete object etc.), how the strategy and the presentation form the student chose made the solution easier should be underlined instead of the result in the problem solving process. The program aims to develop the sub-skill of "expressing mathematical thoughts by using representation forms such as concrete models, figures, pictures, charts, tables etc." to make students gain communication skills. It is underlined in the program that in order to enable learners gain association skills, students should be asked to make comparisons between concepts and rules and to solve problems with which they can make associations between concrete and abstract presentation forms [28].

The basic vision of both primary school and the updates secondary school mathematical program $\left(5^{\text {th }}, 6^{\text {th }}, 7^{\text {th }}\right.$ and $8^{\text {th }}$ grades) [27] is the principle that "Any child can learn mathematics". Principles like "students should be helped in deducting meanings from concrete experiences and making abstractions" and "realistic learning environments should be created" are stated in learning and teaching approach section of the secondary school mathematics program. The basic principles expected to be developed are listed as follows.

1) Problem solving

2) Mathematical process skills (communication, reasoning, association)

3) Affective skills

4) Psychomotor skills

5) Information and communication technologies (ICT) 
It is seen in the updated secondary education (high school) mathematics curriculum [32] that "mathematical modeling and problem solving" skill is the first skill among 5 basic skills and qualifications that the program aims to make students gain. Modeling process is defined in the program as a process "that is completed by mathematizing the mathematical modeling problem starting with a real life problem and interpreting the results that is obtained for real life". It is underlined that importance is given in the program to the creation of learning environments based on problem solving in order to develop modeling skills of the students. Later, the stages of problem solving process are presented as follows:
1) Understanding the problem
2) Making plans
3) Implementing a plan
4) Checking the accuracy and validity of the solution
5) Generalizing the solution and posing new/unique problems.

As a result, it is seen that while "mathematical modeling" skill is not included in primary school and secondary school mathematics program, which is developed by MNE and applied throughout our country, as basic skills and qualifications aimed to be developed, it is included in high school mathematics program. However, when the relation between "modeling and problem solving" skill aimed to be developed in students by the curriculum and the mathematics curriculum of the 9th grade is considered, it is seen that modeling is expressed as "using sets, equations and inequalities, functions, similarities in triangles and trigonometric ratios in right triangles in modeling and problem solving".

However, when the relation between "modeling and problem solving" skill aimed to be developed in students by the program and the mathematics program of the 10th grade, it is seen that modeling is expressed as "using second-degree equations, lengths, areas and volumes of geometric objects and real life problems of concepts regarding probability in modeling and problem solving". We can say that similar expressions are used for the $11^{\text {th }}$ and $12^{\text {th }}$ grades. Right after that gains students should have according to their learning area are given. Therefore, although "modeling skill" is included in the basic skills that are aimed to be developed in highs school mathematics program, it is determined that how "the mathematical modeling" process will occur in learning-teaching process and whether or not there are application examples or activities that will help teachers in relation to this are not mentioned. Although model examples are encountered in activities included in primary school and secondary school mathematics programs, we can say that activity examples with which students will be able to fully apply the steps of the modeling process and which we can call as "modeling activity" are not presented. For example, gains and a model example regarding the $5^{\text {th }}$ grade "natural numbers" topic are presented below.

The desired steps of given numbers and figure patterns for which the rule is given.

It is limited to arithmetic sets and arithmetic set concept is not mentioned.

For example,

Find the $6^{\text {th }}$ item of the number string that is formed by starting from 7 and adding 3 each time.

How many butterflies will Büşra, who started her collection with 7 butterflies in the first week, have if she adds 3 butterflies to her collection every week 5 weeks later?

In this sense, we can say that this topic in question is not adequately covered in primary school, secondary school and secondary education mathematics program applied in our country to provide guidance and support to teachers in classroom.

\section{Discussion and Conclusions}

According to Lesh and Doerr; In recent years, studies on the use of modeling activities in mathematics, most of which have been mostly carried out abroad, have revealed that modeling activities are extremely useful tools for mathematics education [7]. In many countries there is a tendency to give a larger place to mathematical modeling in curriculums. It is emphasized that mathematical modeling is one of the main objectives mathematics instruction in secondary school curriculum in Germany. For instance, in Germany "mathematical modeling skill" is among the 6 basic skills in new "educational standards" in mathematics in Germany [4]. As a result, it can be argued that mathematical modeling is not used commonly from elementary schools to universities and teachers do not sufficiently know its theoretical basis. Even though mathematical modeling is given place in the MNE mathematical education program which has been implemented since 2005, samples of modeling circle and application do not achieve desired level of profoundness and significance.

In Turkish the concept of model is defined as "an object, a person or a form with a certain characteristic", we can say the concept of "modeling" does not have an equivalent. The concept of modeling in physics is used to indicate "showcasing a term related to physics, an atom or a molecule by drawing on a piece of paper or a model". The topic of modeling is superficially studied in mathematics education programs. Similarly, it is seen that there are not courses about modeling in teacher education or especially in mathematics teacher education. In its broadest sense, mathematical modeling is the process of a problem solving by the mathematical expression of real life event or a problem. This process enables learners to relate mathematics to real life and to learn it more meaningfully and permanently.

Mathematical literacy was defined in PISA 2012 as a person's capacity to use, interpret and formulate mathematics in various situations [29]. PISA Mathematical Literacy Sufficiency Levels are formed of 6 stages. It is expected for the students at the $4^{\text {th }}$ level and above $\left(5^{\text {th }}\right.$ and $6^{\text {th }}$ levels) to 
develop skills for working efficiently with the modeling activities, developing and using models and creating concepts and generalizations in their own modeling works [27]. Because of the importance given to "mathematical modeling" in the education programs in countries throughout the world and the international examinations such as PISA, we have to attach necessary importance to this topic in order to not fall behind the modern understanding of education.

It is suggested in primary education and secondary education mathematics programs developed based on constructive learning theory, which was put into use in 2005 and which was updated later, that students should be made to study on model formation activities. While "modeling and problem solving skill " is the first among basic skills and qualifications which are aimed to be given to students in secondary education mathematics program, it is implicitly included as one of the basic skills and qualifications that should be given to students in primary and secondary school mathematics programs. However, it is seen that model examples are presented frequently during the activities in primary school and secondary school programs and activities and model examples are not presented frequently in secondary education program. In this sense, it is necessary to examine theoretical structure of "modeling" topic more deeply in mathematics programs and the modeling activities should be included in mathematics programs. As a result, in MNE mathematics curriculum, the theoretical structure of "modeling" is to be given in more details and modeling activities are to be given. There must be a consistency between elementary school and secondary school and high school mathematics course syllabuses in terms of modeling. In a study by Çiltaş and Yilmaz [6] which they carried out with 144 prospective teachers to determine their ability to express mathematical theorems as mathematical models, it was determined that prospective teachers could not draw mathematical models suitable for relevant theorems or constructed wrong models. This indicates that prospective teachers are not adequately trained in pre-service education to be equipped to use this approach in practice. For this reason, it is necessary for teachers and academicians in the university to have some important competencies. Necessary suggestions are listed below:

- It is necessary to support teachers in terms of learning materials and resources prepared according to the modeling approach for modeling approach to be used widely in MNE schools. As expressed by Blum and Ferri [4], lecture activities during which students experience modeling cycle step by step and make applications should be prepared by program development experts and branch teachers and teachers should be provided necessary support for this. Such kind of modeling activities should be included in mathematics programs and mathematics textbooks more.

- When the leading universities in the world are examined, it is seen that "mathematical modeling" lectures are given in "mathematics and statistics school" in Sydney University, "Mathematical Modeling and Scientific Computing" lectures are given in the Mathematics Institute of Oxford University and "Mathematical Modelling in Finance" lectures are given in Manchester University. It is seen that mathematical modeling lectures are given in engineering faculties of some universities in our country (METU Food Engineering undergraduate lectures and Cumhuriyet University, Department of Mechanical Engineering doctorate lecture). However, "modeling in mathematics education" lectures should be made compulsory in primary school mathematics education departments, secondary education mathematics educations departments or even in primary education departments in education faculties of the universities [30]. Teachers and faculty members have an important place in terms of teaching modeling topic. Modeling topic has an important role in terms of raising and educating teachers. Teacher candidates in higher education should study mathematical modeling topic [12]. Thus, it can be easy for the teacher candidates, who encounter modeling approach before their service, to put this teaching approach into practice. For example, a teacher education program that aims to use teaching of mathematics by means of an approach based on a daily life problem perspective was developed in Italy [29]. A teacher education program, in which modeling approach is used, can be developed and implemented in our country too.

- Mathematical modeling is to be attached greater importance and used more in mathematics syllabus when developing constructivist mathematical course books and other materials.

- Teachers are to be given in service education and studies on teachers are to be carried out to determine to what extent they adopt mathematical modeling approach and develop activities and lesson plans based on modeling approach.

- MNE and universities are to cooperate to carry out more comprehensive research and projects. In this context, joint studies with countries in which mathematics education is applied should be carried out and supported by the MNE.

- Just like Freduenthal Institute in the Netherlands where Realistic Mathematical Instruction is developed, projects are developed and materials are developed to support teachers, research centers within Turkish universities which study the applications of modeling approach in mathematics and in other fields of study can be founded.

We can say that using models in mathematics teaching is necessary to motivate the students, eliminate their fear and anxiety and allow them to develop a positive approach towards mathematics in addition to its many cognitive benefits such as realizing meaningful learning, establishing a relation between mathematics and daily life and developing problem solving skills. In a study by Cansiz [5] titled as "the 
effects of using models with the constructivist learning method, it was determined that the students in the experimental group outperformed the students in the control group in which the traditional method was used. Besides, it was also determined that the students showed positive attitudes towards mathematics when using modeling approach.

\section{REFERENCES}

[1] Bayazıt, İ., Aksoy, Y. and Kırnap, S.M. Öğretmenlerin Matematiksel Modelleri Anlama ve Model Oluşturma Yeterlilikleri. E-journal of New World Sciences Academy Education Sciences. Vol.6, No.4, 2011.

[2] Boaler, J. Mathematical Modelling and New Theories of Learning. Teaching Mathematics and its Applications. Vol. 20, No. 3, 121-128, 2001.

[3] Blum, W. ICMI Study 14: Applications and Modelling In Mathematics Education. Educational Studies in Mathematics No.51, 149-171, 2002.

[4] Blum, W., Ferri, R.B. Mathematical Modelling: Can It Be Taught and Learnt? Journal of Mathematical Modelling and Application. Vol.1, No.1, 2009. ISNN 2178-2423.

[5] Cansız, M. "Yapısalcı Öğrenme Yaklaşımıyla Model Kullanmanın Öğrencilerin Matematiğe Karşı Tutumlarına ve Genelleme Becerilerine Etkisi." Master's Thesis, Trabzon: Karadeniz Teknik Üniversitesi, 2002.

[6] Correjo, D.J., Marshall, J. What is Mathematical Modelling? Exploring Prospective Teachers' Use of Experiments to Connect Mathematics to the Study Of Motion. Mathematics Education Research Journal, Vol. 19, No. 1, 2007.

[7] Çiltaş, A., Yılmaz, K. İlköğretim Matematik Öğretmeni Adaylarının Teoremlerinin İfadeleri İçin Kurmuş Oldukları Matematiksel Modeller. Journal of Research in Education and Teaching, Vol.2, no.2, p.107-114, 2013.

[8] Dede, A. , Güzel, E. Matematik Öğretmenlerinin Model Oluşturma Etkinliği Tasarım Süreçlerinin İncelenmesi: Obezite Problemi. Illkögretim Online, 12(4), 2013.

[9] Doruk, B.K. "Değerler Eğitimi İçin Kullanışlı Bir Araç Olarak Matematiksel Modelleme Etkinlikleri." Kuram ve Uygulamada Ĕgitim Bilimleri, 12(2), 2012.

[10] Doruk, B.K. ve Umay, A. "Matematiği Günlük Yaşama Transfer Etmede Matematiksel Modellemenin Etkisi" Hacettepe niversitesi Eğitim Fakültesi Dergisi, no.41, 2011.

[11] Ferri, R.B. The Teacher's way of handling modelling problems in the classroom- What can we learn from a cognitive- psychological point of view. Research paper for MADIF 5, Malmö, Sweden, 2006.

[12] Ferri, R.B. Mathematical Modelling in School and in Teacher Education- Conceptions and Examples. Santiago de Chile, 2013. Retrived from http://seminaris.conectaideas.com

[13] Heuvel-Panhuizen, M. V. D. The Didactical Use Of Models İn Realistics Mathematics Education: An Example From a Longitudinal Trajectory On Percentage. Educational Studies In Mathematics. No.54, 9-35, 2003.
[14] Johnson, B. Ve Christensen, L. (Trans.. Edi. DEMIR, S.B.) Educational Research, Quantitative, Qualitative and Mixed Approaches, Ankara: Eğiten Kitap, 2014.

[15] Koç, G. Yapılandırmacı Öğrenme Yaklaşımının Duyuşsal ve Bilişsel Öğrenme Ürünlerine Etkisi, Doctoral Thesis, Hacettepe Üniversitesi, Ankara, 2002.

[16] Niss, M. Models and Modelling in Mathematics Education. Mathematics Education, EMS Newsletter December, 2012.

[17] OECD. PISA 2012 Mathematics Framework To OECD, November 30, 2010

[18] Olkun, S., Toluk Uçar, Z. İlköğretimde Etkinlik Temelli Matematik Öğretimi. Eğiten kitap, Turkey, 2012.

[19] Olkun, S.; Şahin, Ö.; Akkurt, Z.; Dikkartın, F.T. ve Gülbağcı, H. Modelleme Yoluyla Problem Çözme ve Genelleme: İlköğretim Öğrencileriyle Bir Çalıșma. Eğitim ve Bilim. Vol. 34, No. 151, 2009.

[20] Özdemir, E., Üzel, D. A Case Study On Teacher Instructional Practices İn Mathematical Modelling. TOJNED- The Online Journal of New Horizons In Education. Vol.3, No.1, 2011.

[21] Pesen, C. Yapılandırmacı Öğrenme Yaklaşımına Göre Matematik Öğretimi. Ankara: Pegem, Turkey, 2008.

[22] Sönmez, V. and Alacapınar, F.G. Örneklendirilmiş Bilimsel Araştırma Yöntemleri. Ankara, Anı, 2013.

[23] Spandew, J., Zwaneveld, B. Modelling In Mathematics' Teachers' Professional Development. Proceedings of CERME 6, January 28th- February 1st, Lyon, France, 2009.

[24] Tekin, A., Kula, S., Hıdıroğlu, Ç.H., Bukova Güzel, E., Uğurel, I. Deterining The Views of Mathematics Student Teachers Related to Mathematical Modelling. 35th Conference of the International Group fort he Psychology of Mathematics Education, Middle East Technical University, 10-15 July, Turkey, 2011.

[25] White, A. "Mathematical Modelling and the General Mathematics Syllbaus" Curriculum K-12 Directorate, NSW Department of Education and Training, 2001.

[26] Wigley, A. "Models for Teaching Mathematics" ATM- The Association of Teachers of Mathematics, 2008.

[27] İlköğretim Matematik Dersi Öğretim Programı ve Kılavuzu 6-8. Siniflar (Taslak Basım), Ankara, MEB Talim ve Terbiye Kurulu Başkanlığı, 2013. Retrieved from http://ttkb.meb.gov .tr

[28] İlköğretim 1-5. Sınıf Programları Tanıtım Kitapçı̆̆ı (IPTK), 2005. Retrived from http://iogm.meb.gov.tr/files/io1-5sinifprogramlaritanitimkit. pdf

[29] Avrupa'da Matematik Eğitimi: Temel Zorluklar ve Ulusal Politikalar- Eurydice. Avrupa Komisyonu, 2011. Retrieved from http://eacea.ec.europa.eu/education/eurydice.

[30] School of Mathematics and Statistics. Retrieved from www.maths usyd.edu.au.

[31] PISA Türkiye, Yenilik ve Eğitim Teknolojileri Genel Müdürlüğ̈̈/ EĞİTEK, 2011. Retrieved from http://yegitek.meb.gov.tr

[32] Ortaöğretim Matematik Dersi (9,10, 11 ve 12. Sınıflar ) Öğretim Programı, Ankara, MEB Talim ve Terbiye Kurulu Başkanlığı, 2013. Retrieved from http://ttkb.meb.gov.tr 